Dept. of Pathology, Animal Health Research Institute, Mansoura Laboratory.

\title{
MUCOID ENTEROPATHY AS FIELD PROBLEM IN RABBIT FARMS IN DAKAHLIA GOVERNORATE
}

(With 4 Tables and 10 Figures)

\author{
By
}

\section{SH. ABDEEN and M.M. ABD EL LATIF*}

* Dept. of Bacteriology, Animal Health Research Institute, Mansoura Laboratory.

(Received at 15/3/2011)

\section{ميوكويد انتيروباثي كمشكلة حقلية في مزارع الأرانب في محافظة الدقهلية شاكر عابلين حسنين ، محمود محدل محمود عبل اللطيف}

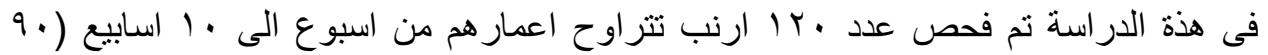

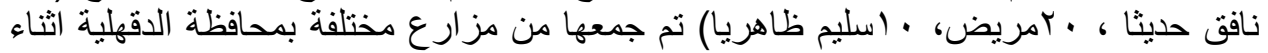

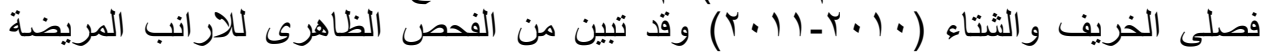

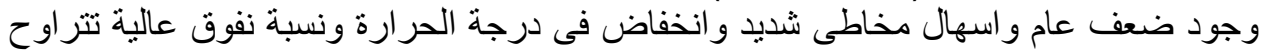

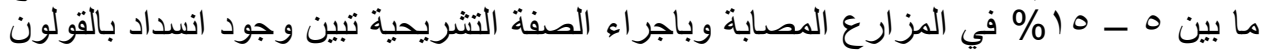

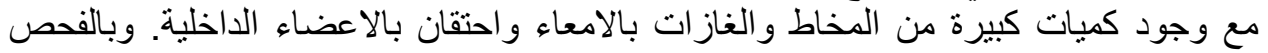

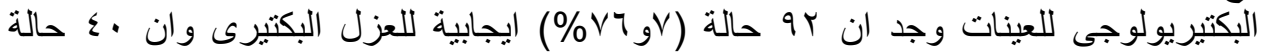

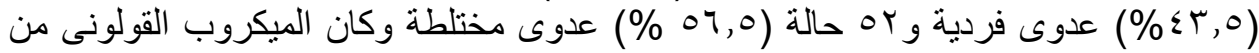

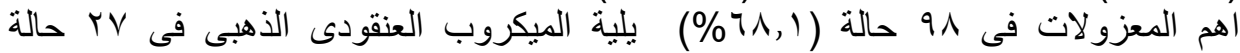

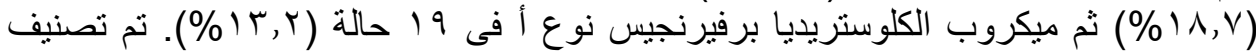

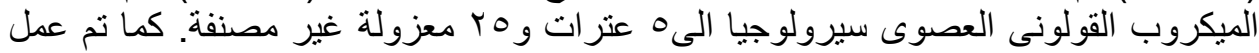

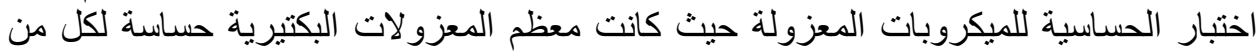

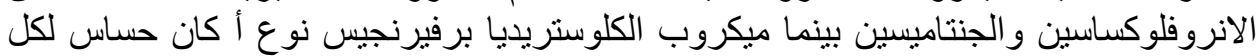

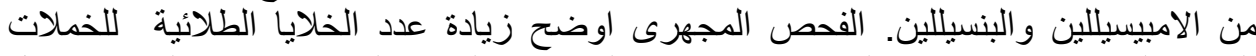
المبطنة للامعاء وسقوط قمم الخملات مع وجود العديد من الخلايا الطلائية مكونة المخاط بدائ بداخل

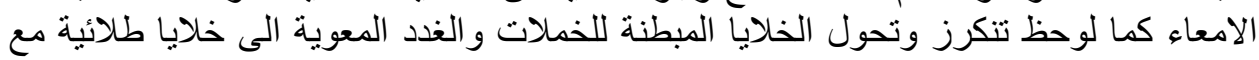

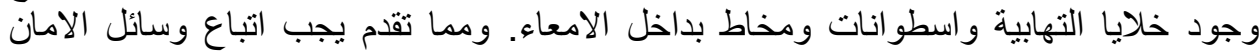

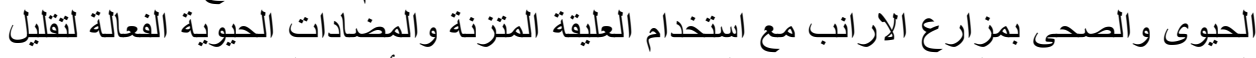
الخسائر الاقتصادية الناجمة عن مرض الميوعو الإنيد انتيروباثي في الأر انب الصغيرة.

\section{SUMMARY}

This work was carried out on 120 rabbits (90 dead, 20 diseased and 10 apparently healthy) of different breeds during autumn and winter seasons (2010-2011), their ages varied from one to 10 weeks. The suspected cases were collected from different private farms in Dakahlia Governorate. The 
clinical sings were abdominal distention, subnormal temperature, polydepsia, anaroxia, severe watery mucoid diarrhea and high mortality rate from 5-15\% among infected farms. The necropsid rabbits revealed partial or complete obstruction of colon with large plug of clear gelatinous mucous. Moreover, the other portions of gastrointestinal tracts were filled with fluid or pasty content together with gas. Liquid or dried fecal matter and mixed or coated with mucous were seen in the intestine of some examined rabbits. Bacteriological examination of the samples showed 92 (76.7\%) positive bacterial isolation of which 40 (43.5\%) single isolates and $52(56.5 \%)$ mixed isolates. E. coli was isolated at incidence percentage 98(68.1\%), Staph. aureus 27 (18.7\%) and Closteridium perfringens type A $19(13.2 \%)$. E. coli isolates were identified serologically into 16 (O119), 12 (O124), 15 (O125), 12 (O126) and 18 (O128) together with 25 untypable isolates. In vitro sensitivity pattern of isolated strains proved that Enrofloxacin and Gentamycin were the most effective drugs for most isolates while the Clostridium perfringens type $A$ isolates were sensitive to Penicillin and Ampicillin. Histopathologically, the lesions were mainly confined to small and large intestines as a target organs. Goblet cell metaplasia among the epithelium of the intestinal villi and glands were noticed, accompanied with desquamated epithelial shreeds and mucous were observed inside the intestinal lumen. In severe cases necrosis and desquamation of intestinal tips were seen in some rabbits. Inflammatory cells with mucous and epithelial cast could be observed in the intestinal lumen in complicated cases. It could be concluded that good hygienic conditions, balanced nutrition and effective antibiotics play an important role in prevention and control of mucoid enteropathy in young rabbits.

Key words: Rabbits, mucoid enteropathy, antibiogram, entevitis.

\section{INTRODUCTION}

Rabbit production is a growing industry in Egypt, which proved economically profitable, digestive disorders are the main cause of morbidity and mortality in fattening rabbits and is responsible for important economic losses among rabbit farms (Okerman, 1987; Hatab and Moustafa, 2007).

At the end of 1996 a new clinical syndrome has emerged in French intensive enclosed rabbit farms. This disease was first named enterocolitis and is now called epizootic rabbit enteropathy (LeGall et al., 1998; Licois, 1998; Licois and Caudert, 1999). This disease has spread from France to other countries and is now endemic on the European countries. The 
mortality rate at onset of the epizooty were (30-80\%) (Licois et al., 1998; Marlier and Vindevogel, 1998; Licois et al., 2005). This disease was observed in Egypt among rabbit farms causing severe losses in last years.

Mucoid enteropathy (MEP) is a distinct diarrheal disease of rabbit characterized by minimal inflammation, hyper secretion and accumulation of mucus in small and large intestines. It may occur due to fed of the young rabbits on low fiber and high starch diets results in high concentration of starch in the cecum and colon which facilitate invasion of intestinal mucosa by different intestinal flora. Bacterial toxins produced during the fermentation process may damage the mucosal surface (Wilber, 1999). Predisposing factors included stress, enzyme deficiency, change in acidity of the cecum, dietary changes, infectious agents and enterotoxins were responsible for occurrence of (MEP) (Brown 2002). Enteropathogenic $E$. coli was the most predominant causative agent of mucoid enteropathy in young rabbits sometimes accompanied with other bacteria as Clostridium spp., Staph. aureus and Klehsiella spp. (Dean et al., 1993; Licois, 2004; Lavazza et al., 2008; Hassan et al., 2009).

This study was designed to investigate mucoid enteropathy as field problem in rabbit farms with special emphasis on its clinical signs, pathological lesions, isolation and identification of the bacterial agents and antibiotic sensitivity pattern for the bacterial isolates.

\section{MATERIALS and METHODS}

\section{Samples:}

This study was applied on 120 rabbits (90 freshly dead, 20 diseased and 10 apparently healthy) of different breeds during autumn and winter seasons (2010-2011). Their ages ranged from one to 10 weeks old and were obtained from different private farms in Dakahlia Governorate. Clinical signs and post mortem lesions suggestive presence of MEP. Samples from liver, spleen, kidney, small and large intestine, heart blood and the content of the caecum of freshly dead and diseased rabbits and cloacal swabs were taken from apparently healthy rabbits.

\section{Bacteriological examination:}

All samples were inoculated into nutrient broth, cooked meat broth and selenite F-broth and incubated at $37^{\circ} \mathrm{C}$ for $18-24$ hours followed by subculturing on nutrient agar, 5\% sheep blood agar, MacConky's agar and Xylose lysine deoxycholate agar plates (Oxoid) and incubated aerobically and anaerobically at $37^{\circ} \mathrm{C}$ for $18-24$ hours. The growing colonies on various plates were described for their appearance, haemolytic activity and 
morphological characters. Smears from the colonies were stained with Gram stain and examined microscopically then divided according to staining,reaction and shape. The isolates were identified biochemically (1ndole, Nitrate reduction, Citrate utilization, H2S production, Gelatin liquefaction, Urease test, Naglers test, Sugar fermentation and Coagulase test) according to Cruickshank et al. (1982); Finegold and Martin (1982) and Koneman et al. (1994).

\section{Serological identification of $E$. coli:}

Serological identification of purified E...coli strains using available agglutinating coli test sera (Behring Werk, AG Marburg) according to manufacturer's Instruction. Labn, Germany).

\section{In vitro antibiotic sensitivity test:}

The disc diffusion technique was performed on the isolated bacteria using Muller Hinton agar media (Oxoid). The chemotherapeutic disks were Enrofloxacin, Gentamycin, Erythromycin, Oxytetracycline, Ampicillin, Penicillin, Amoxycillin and Trimethprim Sulphamethoxazole. The degree of sensitivity was interpreted according to Koneman et al. (1994); Quinn et al. (1994); Oxoid Manual (1998).

\section{Pathological examination:}

Postmortem examination had been done to the freshly dead and diseased rabbits.Specimens from different segments of small and large intestine, were collected and fixed in $10 \%$ neutral buffered formalin. Paraffin sections of 5 microns thickness were prepared and stained with $\mathrm{H}$ \& E according to Bancroft et al. (1996).

\section{RESULTS}

\section{Bacteriological study:}

\section{Clinical signs:}

The main clinical signs of diseased rabbits were high mortality (5-15\%) deaths among different farms, ruffled fur, depression, off food, abdominal distention and mucoid diarrhea.

\section{Postmortem lesion:}

Affected rabbits showed complete obstruction of colon with large plug of clear gelatinous mucous. In severe cases, mucous cord impact the lumen of large intestine mainly cecum (Fig.1). Liquid or dried fecal matter mixed or covered with mucous were seen in the intestines of some other rabbits. The results of bacteriological examination were recorded in tables $1,2,3$ and 4 .

Table 1: Bacteriological examination of rabbits 


\begin{tabular}{|c|c|c|c|c|c|c|c|c|}
\hline \multirow{2}{*}{$\begin{array}{c}\text { Source of } \\
\text { samples }\end{array}$} & \multirow{2}{*}{$\begin{array}{c}\text { Total } \\
\text { No. of } \\
\text { samples }\end{array}$} & \multicolumn{2}{|c|}{$\begin{array}{c}\text { Positive } \\
\text { samples }\end{array}$} & \multicolumn{2}{|c|}{$\begin{array}{c}\text { Single } \\
\text { isolates }\end{array}$} & \multicolumn{2}{|c|}{$\begin{array}{c}\text { Mixed* } \\
\text { isolates }\end{array}$} & $\begin{array}{c}\text { Total } \\
\text { No. of } \\
\text { isolates }\end{array}$ \\
\cline { 5 - 9 } & No. & $\%$ & No. & $\%$ & No. & $\%$ & 4 \\
\hline $\begin{array}{c}\text { Apparently } \\
\text { healthy rabbits }\end{array}$ & 10 & 4 & 40.0 & 4 & 100.0 & 0 & 0.0 & 4 \\
\hline $\begin{array}{c}\text { Diseased } \\
\text { rabbits }\end{array}$ & 20 & 16 & 80.0 & 6 & 37.5 & 10 & 62.5 & 26 \\
\hline Dead rabbits & 90 & 72 & 80.0 & 30 & 41.7 & 42 & 58.3 & 114 \\
\hline Total & 120 & 92 & 76.7 & 40 & 43.5 & 52 & 56.5 & 144 \\
\hline
\end{tabular}

*Mixed infection with two microorganisms.

Table 2: Incidence of bacteria isolated from examined rabbits

\begin{tabular}{|c|c|c|c|c|c|c|c|c|}
\hline \multirow{2}{*}{$\begin{array}{c}\text { Bacterial } \\
\text { isolates }\end{array}$} & \multicolumn{2}{|c|}{$\begin{array}{c}\text { Apparently } \\
\text { healthy } \\
\text { rabbits }\end{array}$} & \multicolumn{2}{|c|}{$\begin{array}{c}\text { Diseased } \\
\text { rabbits }\end{array}$} & \multicolumn{2}{|c|}{ Dead rabbits } & \multicolumn{2}{|c|}{ Total } \\
\cline { 2 - 10 } & No. & $\%^{*}$ & No. & $\%^{*}$ & No. & $\%^{*}$ & No. & $\%^{* *}$ \\
\hline E. coli & 3 & 3.3 & 16 & 17.4 & 79 & 85.9 & 98 & 68.1 \\
\hline Staph.aureus & 1 & 1.1 & 7 & 7.6 & 19 & 20.7 & 27 & 18.7 \\
\hline $\begin{array}{c}\text { Cl.perfringens } \\
\text { type A. }\end{array}$ & 0 & 0.0 & 3 & 3.3 & 16 & 17.4 & 19 & 13.2 \\
\hline Total & 4 & & 26 & & 114 & & 144 & 100.0 \\
\hline
\end{tabular}

* The percentage was calculated according to number of positive samples (92).

** The percentage was calculated according to number of total bacterial isolates(144)

Table 3: Serotypes of E. coli isolated from examined rabbits

\begin{tabular}{|c|c|c|c|c|c|c|}
\hline Serotypes & $\mathrm{O}_{126}$ & $\mathrm{O}_{119}$ & $\mathrm{O}_{124}$ & $\mathrm{O}_{125}$ & $\mathrm{O}_{128}$ & Untypable \\
\hline Number & 12 & 16 & 12 & 15 & 18 & 25 \\
\hline
\end{tabular}

Table 4: Antibiotic sensitivity test for the bacteria isolated from examined samples of rabbits

\begin{tabular}{|c|c|c|c|}
\hline Antibiotic disc & E.coli & $\begin{array}{l}\text { Staph. } \\
\text { aureus }\end{array}$ & $\begin{array}{c}\text { Clostridium perfringens } \\
\text { type A. }\end{array}$ \\
\hline Enrofloxacin $\quad 5 u_{g}$ & +++ & +++ & ++ \\
\hline Gentamycin $\quad 10 \mathrm{ug}$ & +++ & +++ & $\mathrm{R}$ \\
\hline Oxytetracycline $30 u_{g}$ & ++ & ++ & ++ \\
\hline Amoxycillin $25 \mathrm{u}_{\mathrm{g}}$ & $\mathrm{R}$ & $\mathrm{R}$ & +++ \\
\hline Ampicillin & $\mathrm{R}$ & $\mathrm{R}$ & +++ \\
\hline Penicillin & $\mathrm{R}$ & $\mathrm{R}$ & +++ \\
\hline $\begin{array}{ll}\text { Erythromycin } & 15 \mathrm{u}_{\mathrm{g}} \\
\end{array}$ & $\mathrm{R}$ & ++ & ++ \\
\hline $\begin{array}{l}\text { Trimethoprim- } \\
\text { Sulphamethoxazol } \\
\qquad 1.25-23.75 \mathrm{ug}\end{array}$ & ++ & ++ & $\mathrm{R}$ \\
\hline
\end{tabular}




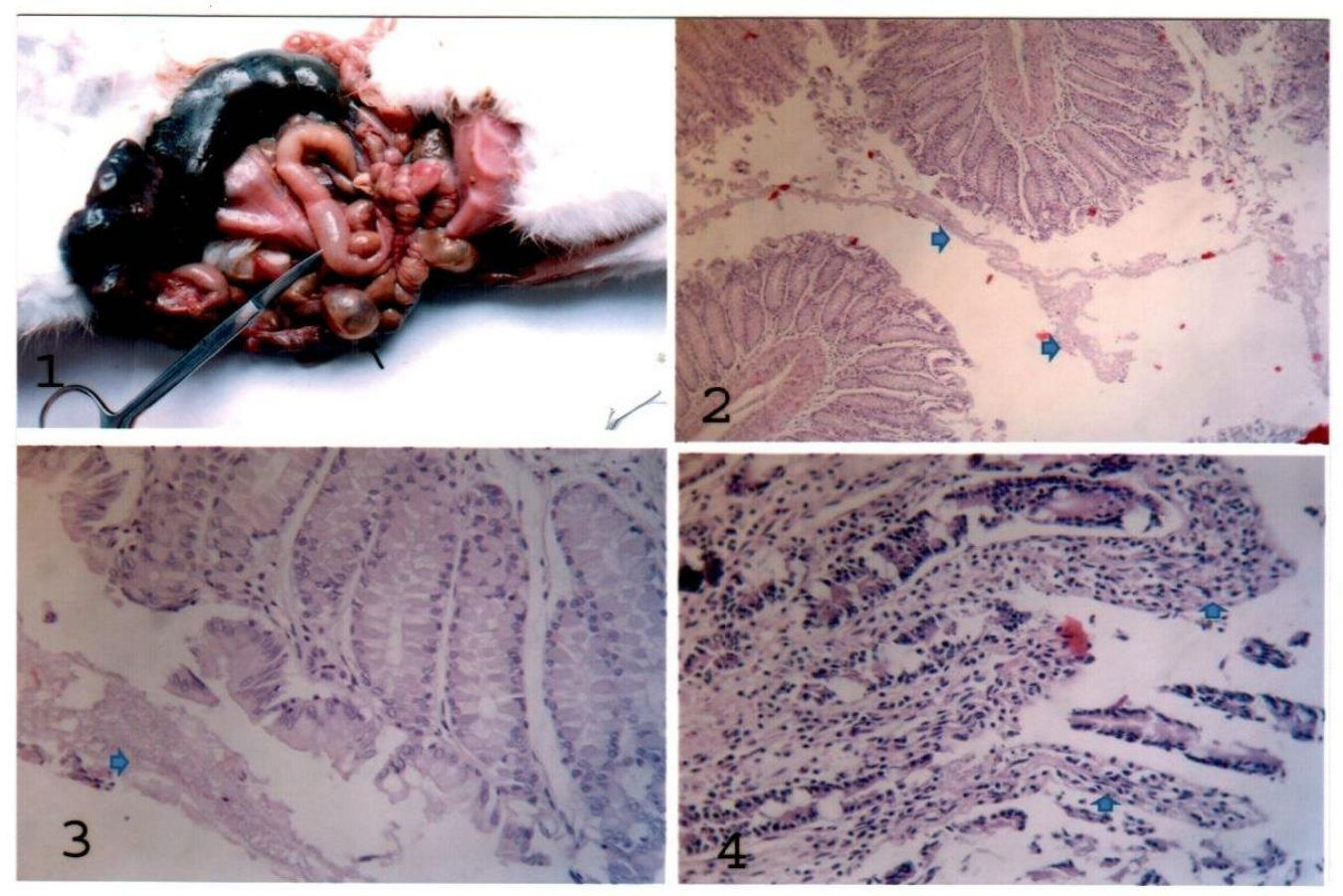

Fig. 1: Intestine of rabbits (MEP) showing presence of muocus (pointer) and gas (arrow) in the intestinal lumen beside impacted dark cacum.

Fig. 2: Large intestine of rabbits (MEP, E. coli) showing little muocus inside the intestinal lumen (arrow) H\&E×300.

Fig. 3: The high power of the previous figure to show muocus and desquamated epithelial shreeds inside the intestinal lumen $\mathrm{H} \& \mathrm{E} \times 1200$

Fig. 4: Small intestine of rabbits (MEP, E. coli) showing severe necrosis and desquamotion of the intestinal tips (arrow) $\mathrm{H} \& \mathrm{E} \times 1200$ 


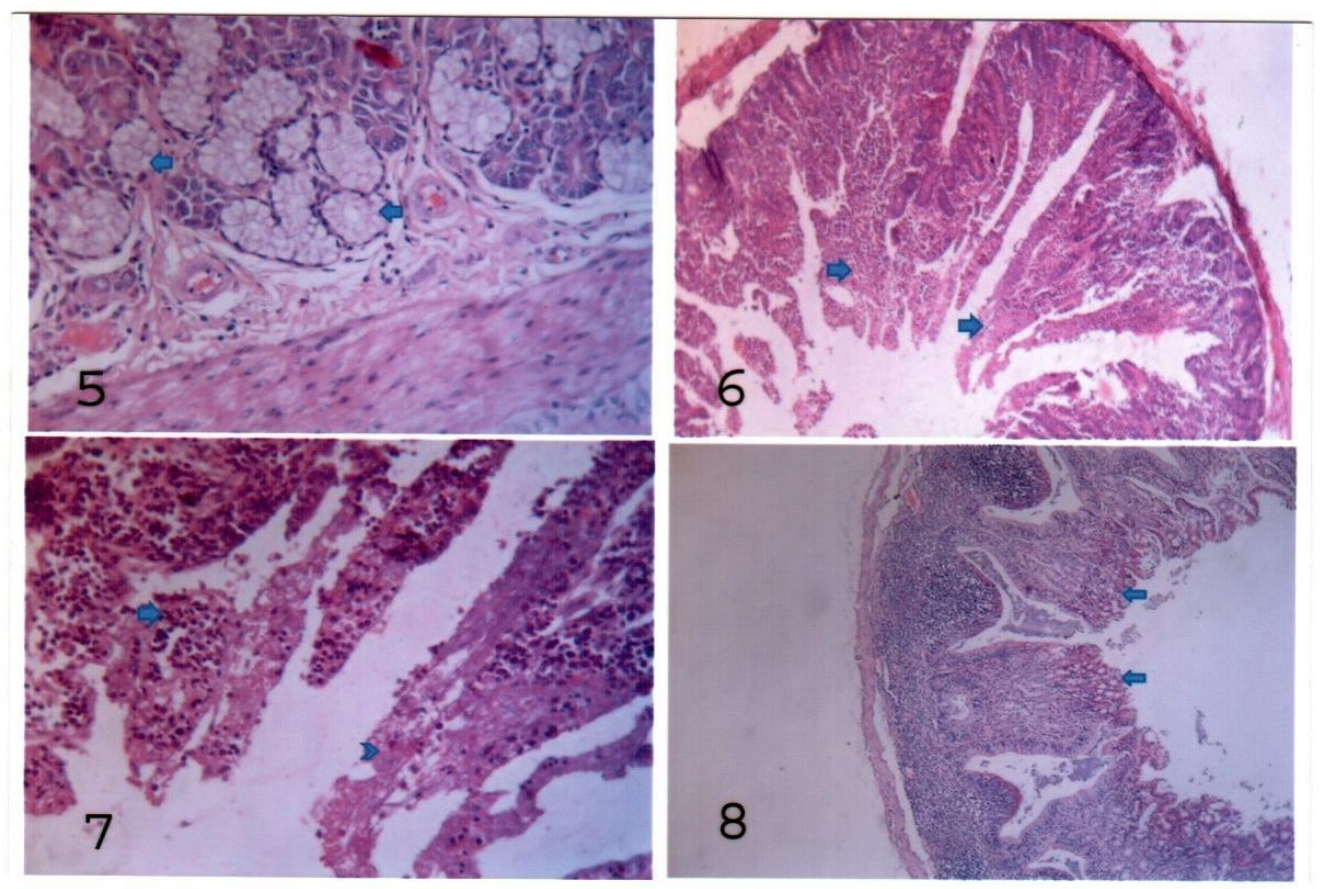

Fig. 5: Small intestine of rabbits (MEP, E. coli) showing metaplasia of the submucosal intestinal gland to goblet cell H \& E × 1200 .

Fig. 6: Small intestine of rabbits (MEP, Clostridium perfringens type A) showing mild infilammatory cells, muocus epithelial cast inside the intestinal lumen (arrow) H \& $\mathrm{E} \times 300$.

Fig. 7: Small intestine of rabbits (MEP, Staph. aureus) suffered from necrosis and severe infiltration of inflammatory cells in the lamina propria $\mathrm{H} \& \mathrm{E} \times 1200$.

Fig. 8: Small intestine of rabbits (MEP, Staph. aureus) showing little muocus and numorous goblet cells on the surface epithelium $\mathrm{H} \& \mathrm{E} \times 30$ 

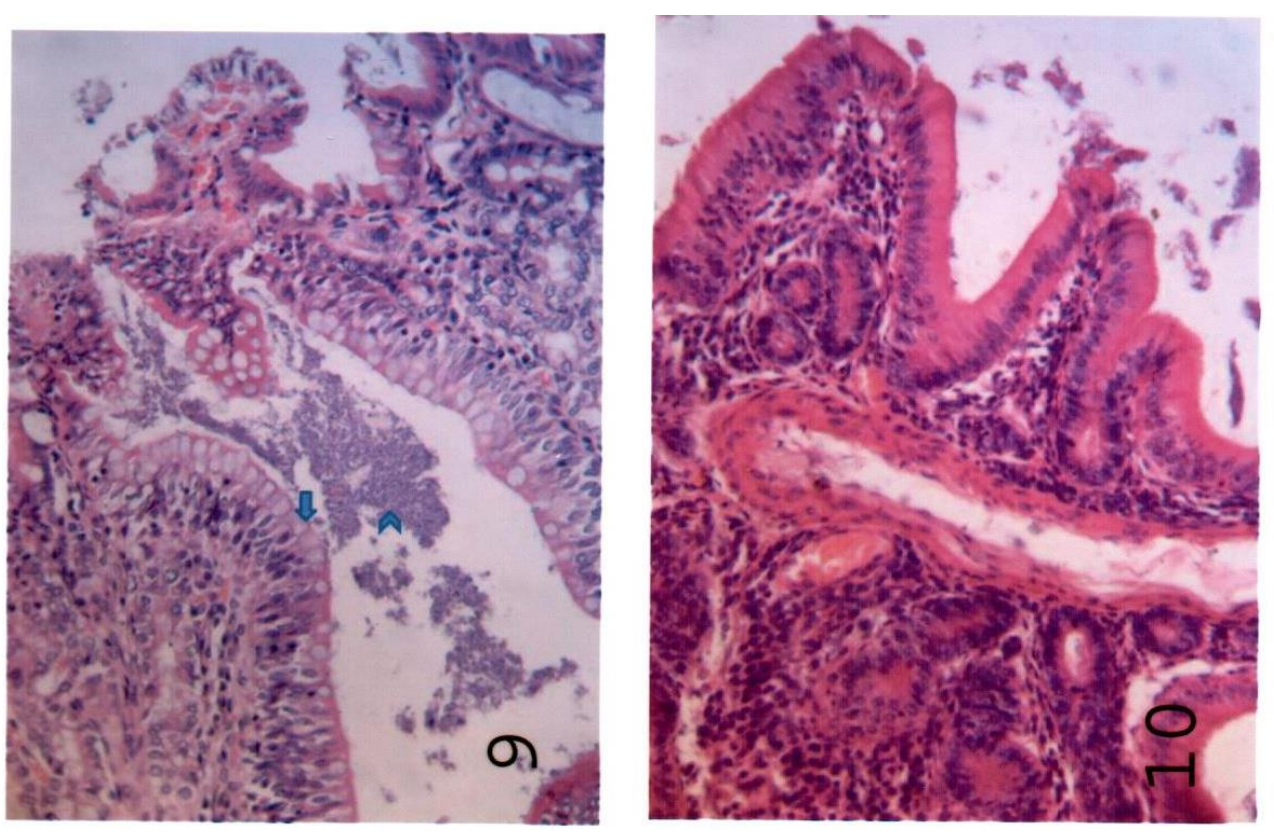

Fig. 9: Small intestine of rabbits (Negative bacterial infection) showing basophllic muocus, numerous goblet cells between the intestinal villi $\mathrm{H} \& \mathrm{E} \times 1200$.

Fig. 10: Apparently normal intestinal coat after treatment $\mathrm{H} \& \mathrm{E} \times 1200$

\section{DISCUSSIONS}

Enteritis is considered the major cause of disease in commercial rabbit industry. Diet, stress and management factors also acknowledged affecting the incidence and spread of enteric disease. Infectious agents known to play a role include parasites, enteropathogenic E. coli (EPEC) Staphylococcus aureus and Clostridium spp. (Percy et al., 1993; Lavazza et al., 2008). The bacterial infections are major health concern of rabbits production, one of the major causes of mortality in rabbits was gastroenteritis (Rai et al., 1985). It was found that 120 cases of examined rabbits $92(76.7 \%)$ revealed bacterial infection from which $40(43.5 \%)$ yielded a single pure isolate and $52(56.5 \%)$ yielded a mixed bacterial isolates (Table 1). On the other hand Hassan et al. (2008) recorded that the bacterial infection in newly born rabbits suffered from diarrhea was in single pure isolate $49(50.52 \%)$ and mixed isolates $48(49.48 \%)$. The clinical signs were depression, off food, emaciation, watery mucoid 
diarrhea and death. The post mortem lesions in this study revealed congestion and edematous of the intestine with watery mucoid content beside congestion in all internal organs. The forementioned results are inagreement with those repored by El. Attar (1985); Rashed (2000); Hassan et al. (2008).

Bacteriological examination of the samples revealed that isolated bacterial pathogens were E. coli 98 (68.1\%), Staphylococcus aureus 27 (18.7\%) and Clostridium perfringens type A. 19 (13.2\%). Lower incidence were recorded by Hassan et al. (2009) who isolated E. coli (45.0\%), Staph. spp.(20.0\%) and Clostridium spp.(5.0\%), from rabbits affected with enteritis. On the other hand Hatab and Moustafa (2007) and Hassan et al. (2008) isolated E.coli, Pasteurella multocida, salmonella spp., Staph aureus, Strept. pyogen, Klebsiella pneumoniae and Pseudomonus auregenosa from diarrheic newly born rabbits. Escherichia coli is a Gramnegative, lactose fermenting, indole positive, facultative anaerobe of the human and animal intestinal flora. The organism typically colonizes the infant gastrointestinal tract within hours after birth, (Brasar and Hill, 1974). E. coli can adhere to the mucus overlying the intestine and destroy the microvilli of intestinal enterocytes. Enterotoxigenic E.coli (ETEC) also adheres to the enterocyte surface and cause disease by producing either heat labile toxin or heat stable toxin (Trenton, 1989). From our results in Table (2) E. coli was the most frequent isolates 98 (68.1\%) which considered the main cause of rabbit mucoid enteropathy and mortality in young rabbits. The obtained results nearly similar to those obtained by (Peeters et al., 1984; Percy et al., 1993; Harcourt and Nigel 2002; Edrees et al., 2008). They concluded that E.coli infection is the most and primary causative agent in most outbreaks of enteritis and diarrhea in young rabbits. From Table (3) its clear that 73 out of 98 identified E.coli isolates could be identified serologically into $12\left(\mathrm{O}_{126}\right), 16\left(\mathrm{O}_{119}\right), 12\left(\mathrm{O}_{124}\right), 15\left(\mathrm{O}_{125}\right) 18$ $\left(\mathrm{O}_{128}\right)$ and 25 untypable, most $E$. coli serotypes isolated from apparently healthy, diseased and dead newly born rabbits were inagreements with those recorded by Ibrahim (1985); Percy et al. (1993); Hatab and Moustafa (2007); Hassan et al. (2008). Staphylococcosis in rabbits is caused by Staph.aureus which was isolated 27 (18.7\%) from $1(1.1 \%), 7(7.6 \%)$ and $19(20.7 \%)$ of examined apparently healthy, diseased and dead rabbits respectively Table (2). Abdel-Gwad et al. (2004) isolated Staph. aureus from diseased rabbits with an incidence of (22.4\%). Also Hatab and Moustafa (2007), Hassan et al. (2008) and Hassan et al. (2009) they isolated Staph. aureus from rabbits suffered from diarrhea with percent of $16.7 \%, 19.6 \%$ and $20.0 \%$ respectively. 
Clostridium perfringens type $A$ were isolated 19(13.2\%) from diseased rabbits $3(3.3 \%)$ and $16(17.4 \%)$ dead rabbits. Higher percentage was recorded by Maghawry and Nasr (2009) who isolated Closteridium spp. (43.8\%) from diarrhoeic rabbits. Some authors isolated Clostridium spp. from diarrhoeic young rabbits (Peeters et al., 1984; Dewree et al., 2007; Edrees et al., 2008; Lavazza et al., 2008; Hassan et al., 2009).

In Vitro sensitivity testing of isolates revealed that the most isolates of E. coli and Staph aureus were highly sensitive to Enrofloxacin and Gentamycin (Table 4). Similar results were reported by Abd El Rahman et al. (2005); Hatab and Abdel-latif (2006); Hassan et al. (2008). Concerning Clostridium perfringens type $A$ it was highly sensitive to Amoxycillin, Ampicillin, Penicillin and Enrofloxacin. Nearly similar result was recorded by Maghawry and Nasr (2009) who found that Clostridium perfringens which isolated from diarrheic rabbit were sensitive to Penicillin and Enrofloxacin.

\section{Pathological studies:}

This study declared the Mucoid enteropathy, resulted in high economic losses among the infected rabbits. These losses due to mortalities $(5-15 \%)$ and reduction in meat gain due to enteric lesions.

Moreover, this syndrome characterized by clinical signs which were depressions, off food, emaciations, watery mucoid diarrhea and ruffled fur. The fore mentions signs were inagreement with Dean et al. (1993); Licois (2004); Ashraf (2004). These signs occurred due to the hyper-secretions and accumulations of mucous in small and large intestine due to feeding on diet of low fiber and high starch. These facilitate the invasion of intestinal mucosa by different intestinal flora (E. coli, Clostridium spp. and Staph.). The bacterial toxins which resulted due to fermentation causing damage the mucosal surface (Wilber, 1999).

The main gross lesions in our work were obstruction of colon with large blood of cleared gelatinous mucous. In severe cases mucous cord impact the lumen of large intestine mainly cecum were common (Fig. 1). Moreover, the other segments of small and large intestine were filled with fluid or pasty content and gases. Similar results were recorded by El-Attar (1985); Coudert et al. (1997); Licois et al. (1998); Rashed (2000); Hassan et al. (2008).

Microscopically, E. coli was isolated in the most examined rabbits (98) at incidence percentage of $(68.1 \%)$. These rabbits showed desquamation of the epithelial lining covering the large intestine with mucous content inside its lumen (Figs. $2 \& 3$ ). The small intestine showing severe necrosis and desquamation of the intestinal tips (Fig. 4). Metaplasia of the submucosal intestinal glands to goblet cells with thickening of the 
muscular coat were also seen (Fig. 5). These results were agreement with those mentioned by Manning et al. (1994); Rashed (2000); Brown (2002); Hassan et al. (2008) who reported the some results in rabbits suffered from mucoid enteropathy with $E$. coli infection. Clostridium perfringens type A were isolated from $19(13.2 \%)$. The small intestine of these rabbits showed mild inflammatory cells, mucous and epithelial casts inside the intestinal lumen (Fig. 6).

Staph. aureus infection $27(18.7 \%)$ in all examined rabbits, the intestinal mucosa suffered from necrosis and sever inflammatory cell infiltration in the lamina propria (Fig.7). Moreover, little mucous and numerous goblet cells on the surface epithelium were seen (Fig.8). Basophillic mucous and numerous goblet cells between the intestinal villi were observed. Negative bacterial infection cases with mucoid enteropathy (Fig. 9). After using the sensitive drugs, the intestine noticed apparently normal without any lesions (Fig.10). Our results were nearly agreement with those obtained by many researchers (Wilber, 1999; Ashraf, 2004; Licois, 2004; Dewree et al., 2007; Hassan et al., 2008).

In our opinion mucoid enteropathy mostly occurred in the young rabbits post weaning due to certain predisposing stress factors such as sudden change in diet, enzyme deficiencies due to immaturity of gastrointestinal tract, feeding on diet of high carbohydrates and low fiber contents. All these factors resulting in changes in the acidity of the intestines with disruption of intestinal microflora. This microflora produced non inflammatory substances which stimulated the secretion of huge amount of mucous from the intestinal epithelium. This hyper secretion of the mucous could be considered as a compensatory mechanism to the hyperacidity of intestine (Check, 1987; Lelkes and Chang, 1987; Brown, 2002).

These investigations throw some lights on mucoid enteropathy syndrome in young rabbits and declared the bacterial pathogens and pathological changes of the intestine. So the good hygienic conditions, balanced nutrition and effective antimicrobial agents play an important role in the prevention and control of mucoid enteropathy in young rabbits.

\section{REFERENCES}

Abdel-Gwad, A.M.; Abdel-Rahman, A.A. and Ali, M.M. (2004): Significance of Staphylococcus aureus in rabbits in Assiut Governorate. Ass. Univ. Bull. Environ. Res. Vol. 7 NO. 1, PP. $77-84$ 
Abd-El-Rahman, A.A.; Neveen, A.H. and Fatma, A.M. (2005): Isolation and pathogenicity of intestinal pathogens associated with enteritis complex in rabbits with special reference to $E$. coli and Salmonella spp. Assiut Vet. Med. J. 51(106): 180-17.

Ashraf, M.F. (2004): Pathological studies on diseased immature rabbits Thesis Ph. D.V.Sc. (Pathology Dep.) Fac. Vet. Med. Zagazig Uni. Bancroft, J.D.; Stevens, A. and Turner, D.R. (1996): Theory and practice of histological techniques $4^{\text {th }}$ Ed. Churchill Livingston, New York, London, San Francisco, Tokyo.

Brasar, B.S. and Hill, M.J. (1974): Human intetinal flora. London, United Kingdom: Academic Press, Ltd, PP. 36-43.

Brown, F.H. (2002): Text book of rabbit Medicine Oxford Auckland Boston Johannesburg. Melbourne, New Delhi.

Checke, P.R. (1987): Rabbit feeding and nutrition pp77: 95-176.Zoo Academic Press. Orlandos, Florida.

Coudert, P.; Lebas, F. and Licois, D. (1997): Une nouvella pathologie ravage Les elevages. La. Profession se mobilize. Cuniculture. 24: 225-229.

Cruickshank, R.; Dugid, J.P.; Marmion, B.P. and Swaim, R.H. (1982): Medical Microbiology, 12th.Ed. Churchill livingestone Edinburgh, London, UK.

Dean, H.P.; Muckle, C.A.; Hampson, R.J. and Brashm, M.L. (1993): The enteritis complex in domestic rabbits a field study. Can Vet. J. Vol. 34, P: 95-102.

Dewree, R.; Meulemans, L.; Lassence, C.; Desmecht, D.; Ducatelle, R.; Mast, J.; Licois, D.; Vindevogel, H. and Marlier, D. (2007): Experimentally induced epizootic rabbit enteropathy: Clinical histopathological, ultrastructural, bacteriological and haemotological findings. World Rabbit Sci. 15 P: 91-102.

Edrees, N.M.; Osama, T.B.; Hashim, M.A. and Alam, R.T. (2008): Clinicopathological studies on the effect of some bacterial infection in rabbits. Zag. Vet. J. (ISSN 1110-1458) Vol. 36, No.2 pp. 199-206.

E1-Attar, SR. (1985): Experimental histopathological studies on the effect of some entero-pathogenic types of Escherichia coli in some experimental animales M.V, SC., thesis pathology Dep., Fac. Vet. Med., Zagazig University.

Finegold, S.M. and Martin, W.J. (1982): Bailey and Scott,s Diagnostic Microbiology. 6th. ed. The C.V. Moshy Co., St. Lowis, Toronato, London. 
Harcourt, B. and Nigel, H. (2002): Clostridial enterotoxaemia in Text book of rabbit medicine $1^{\text {st }}$ Ed., Butterworth Heinemann, Oxford, Auckland, Boston, Johanesburg, Melbourne and New Delhi. 284-285.

Hassan, A.M.; El-Nisr, N.A. and El-Naser, E.M. (2009): Etiological studies of enteritis in commercial rabbits. Assiut Vet. Med. J. Vol. 55 No. 123, p. 226-240.

Hassan, M.M.; Selim, M.A. and Abdeen, S.H. (2008): Pathological and bacteriological stidies on diarrhea in newly born rabbits at Sharkia Province. SCVMJ, X111(2) Suez Canal Vet. Med. J. P: 417-434.

Hatab and Moustafa, A.H. (2007): Some studies on the bacterial causes of mortality in new born rabbits. Assuit Vct. Med. J., 53 (12): 258-268

Hatab, M.E.M. and Abd EL-Latif, M.M. (2006): Studies on some bacteria associated with aboration in rabbits. Assuit Vet. Med. J., 52(109): 285-293.

Ibrahim, A.A. (1985): Colibacillosis of rabbits. Assiut vet. Med. J. 14(27): 243-246.

Koneman, E.W.; Allen, S.D.; Jonda, W.M.; Sehrechenberger, P.C. and Win, W.C. (1994): Introducation to Diagnostic Microbiology. J.B. Lippincott Company, Philadelphia U.S.A.

Lavazza, A.; Cerioli, M.; Martella, V.; Tittarelli, C.; Grilli, G.; Brivio, R. and Buonavoglia, C. (2008): Rotavirus in diarrheic rabbits: prevalence and characterization of strains in Italian farms. $9^{\text {th }}$ World rabbit Congress. Verona-Italy. P: 993-997.

Le Galla, G.; Morisse, J.P.; Picault, J.P.; Allec, C.; Le Bihanmic, P. and Colhn, P. (1998): Essais de reproduction expérimental de l'Etertie Epizootique du Lapin (E.E.L.). In proc. 7eme Journées de la Recherche Counicole, Lyon, France, 13-19.

Lelkes, L. and Chang, C.L. (1987): Micorbial dysbiosis in rabbit mucoid enteropathy. Lab. Anim. Sci. 37: 757-764.

Licois, D. (2004): Domestic rabbit enteropathies. Proceedings-sth world rabbit congress.September 710 2004-puebla Mixico invited paper.

Licois, D. and Coudert, P. (1999): Le point des recherches sur l'entérocolite épizootique du lapin. In proc. 9eme Journées de la Recherche Counicole, Lyon, France, 33-39. 
Licois, D.; Wyers, M. and Coudert, P. (2005): Epizootic rabbit enteropathy. Experimental transmission and clinical characterization Vet. Res. 36 601-613.

Licois, D. (1998): Bilan des travaux réalises a l'INRA sur l'entérocolite épizootique, dans l'hypothèse d'une étiologie virale de la maladie. In Proc 7eme Journées de la Recherche Counicole, Lyon, France, 13-19.

Licois, D.; Vautherot, G.F. and Drambrine, G. (1998): 6,349-353. Modele de reprodnction expermintal enlerocolite epizootique chez des japins eops. World rabbit Sci

Maghawry, M.A. and Nasr, E.M. (2009): The use of western blot technique for toxinotypes of clostridium perfringens isolated from rabbits with enteric diseases. J. Egypt, Vet. Med. Asso. 69, No. 3: 59-73.

Manning, P.J.; Ringler, D.H. and New Comer, C.E. (1994): The biology of laboratory rabbits $2^{\text {nd }} E d$.

Marlier, D. and Vindevogel, H. (1998): L'entérocolite épizootique du lapin. Ann. Med. Vet. 142: 281-284.

Okerman, L. (1987): Prewcaning mortality in rabbits study of pathology and bacteriology. Land Bouwtig Dschrift., 40(5): 1295-1304

Oxoid, (1998): The Oxoid Manual. $8^{\text {th }}$ Ed. Publ. By Oxoid Limited Wade Road, Basingstoke Hampshire RG 248 PW. England .

Peeters, J.F.; Charlier, G.J. and Halen, P.H. (1984): Pathogenicity of attaching effecting enteropathogenic E.coli isolated from diarrhea suckling and weaning for new born rabbits. Infection Immune., 46: 690-696.

Percy, H.; Muckle, C.A.; Robert, J. and Bruch, I.M. (1993): The enteritis complex in domestic rabbits a field study. Can. Vet. J., 34: 95-100

Quinn, P.J.; Carter, M.E.; Markey, B.K. and Carter, G.R. (1994): Clinical Veterianry Microbiology. Published by welfe Publishing.Eurp Limited.

Rai, R.B.; Dhirendra and Singh, R.N. (1985): Studies on mortality pattern in rabbits. Indian Vet. Med. J. 9(1): 26-30

Rashed, E.A. (2000): Studies on bacterial diseases in broiler rabbits. Thesis PHD Vet.Sc. Pollatry disease Dep. Fac. Vet. Med. Zag. University.

Trenton, R.S. (1989): Pathology of laboratory animals Dep. of Comparative Med. Univ. of Alabama at Birmingham.

Wilber, D.D. (1999): Pathology of the rabbit. Dep. Vet. Path. Armed forces Institute of pathology. Washington, D.C. P: 15-19. 
Assiut Vet. Med. J. Vol. 57 No.129 April 2011 